\title{
Active Case Search
}

National Cancer Institute

\section{Source}

National Cancer Institute. Active Case Search. NCI Thesaurus. Code C127515.

Purposefully looking for subjects with a particular characteristic or disease. 